\section{T. K. Sidey Summer-time Award}

IT is announced that the second award of the T. K. Sidey Summer-time Medal and Prize will be made by the Royal Society of New Zealand at its annual meeting in May 1936. The award, which comprises a medal and a prize of $£ 100$, is made for the most valuable contribution or contributions to human knowledge by research in the study of light visible and invisible and other solar radiations in relation to human welfare. Applications will close with the Secretary of the Society on February 29, 1936. Theses specially prepared or copies of published works may be submitted. The first award of this medal was made to Lord Rutherford in 1933.

\section{Melbourne Meeting of the British Medical Association}

THE annual meeting of the British Medical Association will be held in Melbourne on September 9-14, under the presidency of Sir James Barrett, deputy chancellor of the University of Melbourne. The meeting will be divided into the following sections, with the sectional presidents indicated: Medicine, Lord Horder ; Surgery, Sir Thomas Dunhill ; Obstetries and Gynæcology, J. S. Fairbairn; Radiology and Radiotherapeutics, H. M. Moran; Diseases of Children, Dr. Robert Hutchison; Neurology and Psychological Medicine, Prof. E. Bramwell ; Ophthalmology, Dr. A. J. Ballantyne; Orthopædics, Prof. E. W. Hey Groves; Oto- RhinoLaryngology, Francis Muecke; Pathology and Bacteriology, Prof. A. M. Drennan; Pharmacology, Therapeutics and Anæsthesia, Sir William Willcox; Public Medicine, including History of the Development of Medicine in Australia, Sir Henry Gauvain; Dermatology, Dr. S. Watson Smith; Medical Sociology, Dr. E. Kaye Le Fleming. The honorary local general secretary is Dr. J. P. Major, Medical Society Hall, Albert Hall, East Melbourne, C.2.

\section{Announcements}

DR. E. J. Buther, director of the Imperial Myeological Institute, has been appointed secretary to the Agricultural Research Council, in succession to Sir William Dampier. Sir William will be appointed a member of the Council as from the date of his resignation of the secretaryship on September 30 .

THE Medical Research Council has awarded Dorothy Temple Cross Fellowships for the academic year 1935-36, under the terms of the benefaction in that name for research fellowships in tuberculosis, to the following:-Dr. G. B. Brook, senior assistant veterinary officer, Derbyshire County Council ; Dr. J. W. Craig, assistant medical officer, King Edward VII Sanatorium, Midhurst, Sussex; and A. H. B. Rhodes, house physician, Brompton Hospital, London.

Busts of Robert Koch and Conrad Röntgen have recently been placed in the Deutsches Museum at Munich on the occasion of the tenth anniversary of its foundation.
Among various other works of anti-aircraft defence, the Municipality of Prague has decided to build a subterranean hospital containing several hundred beds.

Dr. Arthur Meyer, head of the publishing firm of Johannes Ambrosius Barth at Leipzig, has been awarded the Goethe Medal by the German Chancellor in recognition of his services to German scientific literature. He has also been made a doctor honoris causa by the medical faculty of the University of Leipzig.

The German Society of the History of Medicine, Natural Science and Technique will hold its annual meeting at Bamberg on August 29-September 2. Further information can be obtained from the secretary, Dr. Walter Artelt, Institut für Geschichte der Medizin und Naturwissenschaften, Universitätsstrasse 36, Berlin, N.W.7.

Applications are invited for the following appointments, on or before the dates mentioned :

A chief lecturer in engineering in the Bournemouth Municipal College - The Director of Education, Town Hall, Bournemouth (Aug. 17).

A technical officer in the Meteorological OfficeThe Secretary (S. 2. E.), Air Ministry, Adastral House, Kingsway, W.C.2 (Aug. 22).

An inorganic chemist on the staff of the British Scientific Instrument Research Association, 26, Russell Square, London, W.C.1-The Director of Research (Aug. 23).

A lecturer in mathematics in the University of Reading-The Registrar (Aug. 26).

Lecturers in mechanical engineering and mining engineering in the Denbighshire Technical Institute, Wrexham-The Director of Education, Education Offices, Ruthin (Aug. 26).

A dairy bacteriologist at the County Council Farm, Hutton, near Preston-The Director of Education, County Offices, Preston (Aug. 30).

An assistant lecturer in zoology in the University of Leeds-The Registrar (Aug. 31).

An assistant Government analyst in the Straits Settlements-The Director of Recruitment (Colonial Service), 2 Richmond Terrace, Whitehall, S.W.1 (Aug. 31).

A secretary to the Institution of Naval ArchitectsCouncil, Institution of Naval Architects, 2 Adam Street, W.C.2 (Aug. 31).

A head of the Engineering Department and the Junior Technical School, Municipal Technical College, Blackburn-The Director of Education, Education Offices, Blackburn.

A dairy instructor at the Farm Institute, Sparsholt, near Winchester-L. G. Troup, Agricultural Organiser, 82 High Street, Winchester.

A municipal engineer at Jaffa-Crown Agents for the Colonies, 4 Millbank, Westminster, S.W.1, quoting $\mathrm{M} / 3786$. 